енергії, Вінницький національний аграрний університет (21008, м. Вінниця, вул. Сонячна, 3, e-mail: zakharchenkovn@i.ua).

ZAKHARCHENKO Volodymyr - Doctor of Economic Sciences, Professor of the Department of Administrative Management and Alternative Energy Sources, Vinnytsia National Agrarian University (21008, Vinnytsia, 3, Soniachna Str., e-mail: zakharchenkovn@i.ua).

ЗАХАРЧЕНКО Владимир Иванович - доктор экономических наук, профессор кафедры административного менеджмента и альтернативных источников энергии, Винницкий национальный аграрный университет (21008, г. Винница, ул. Солнечная, 3, e-mail: zakharchenkovn@i.ua).

\section{ЗНАЧЕННЯ \\ ОБЛІКОВОї \\ СКЛАДОВОї \\ ПРОЦЕСУ \\ ЦІНОУТВОРЕННЯ НА ПІДПРИЕМСТВІ}

КОВАЛЬ Л.В., кандидат економічних наук, доцент кафедри бухгалтерського обліку

ЛЕПЕТАН I.M., кандидат економічних наук, доцент кафедри бухгалтерського обліку, Вінницький національний аграрний університет (м. Вінниця)

У статті обтрунтовано значення облікової складової процесу цүіноутворення на підприємстві.

Зокрема, окреслено визначення процесу иіноутворення та встановлено його залежність від ряду факторів. Окрім иьього, в статті наведено стратегію функиіонування суб'єкта господарювання, залежно від його фінансового стану. У результаті изього встановлено, щзо ијіна прямо виливає на поведінку суб'єкта господарювання на ринку. Виокремлено різноманітність ринків, у яких працюють суб'єкти господарювання та визначено їхній вплив на формування цінової політики підприємств. Установлено, щзо для формування цінової політики важливе значення має процес організації обліку такої діяльності. У зв'язку з ичим було представлено існуючі методичні підходи до встановлення изіни.

Визначено, щзо в основу розрахунку ичіни на продукцію покладена інформація про витрати, які понесло підприємство на ї̈ виготовлення. Таку інформацію надають дані бухгалтерського обліку. Окрім цьього, враховуються $i$ зовнішні фактори, які дають можливість розрахувати максимально можливий прибуток від реалізації виготовленої продукиії.

Розглянуто функиї ціни, через яку проявляється ї̈ економічна сутність. Виокремлено, щуо саме за допомогою облікової функції визначаються витрати суспільної праиі, а також вартість потреби суспільства в товарі; завдяки обліковій функції цуіна $\epsilon$ засобом визначення кількісних і якісних показників товарообороту.

Окреслено етапи організації обліку в ціноутворенні й наведена їхня характеристика. Визначено роль $i$ значення облікового апарату в системі ціноутворення суб'єкта господарювання. Виділено елементи облікової політики з прямим $i$ 
непрямим впливом на процес иіноутворення. Доведено управлінський вплив облікової політики на формування ціни підприємства. Окрім цьього, розглянуто етапи иільового изіноутворення.

На основі проведеного дослідження зроблено відповідні висновки й вказані напрямки подальших досліджень і причини їхньої необхідності. політика.

Ключові слова: ціна, витрати, облік, прибутковість, попит, підприємство, облікова

Табл.: 2. Рис.: 3. Літ.: 11.

\title{
THE IMPORTANCE OF THE ACCOUNTING COMPONENT OF THE PRICING PROCESS AT THE ENTERPRISE
}

\author{
KOVAL Liubov, \\ Candidate of Economic Sciences, \\ Associate Professor of the Department of Accounting
}

\author{
LEPETAN Inna, \\ Candidate of Economic Sciences, \\ Associate Professor of the Department of Accounting, \\ Vinnytsia National Agrarian University \\ (Vinnytsia)
}

\begin{abstract}
The article substantiates the importance of the accounting component of the pricing process at the enterprise.

In particular, the definition of the pricing process is outlined and its dependence on a number of factors is established. In addition, the article presents the strategy of the entity, depending on its financial condition. As a result, it is established that the price directly affects the behavior of the entity in the market. The diversity of the markets in which business entities operate is highlighted and their influence on the formation of the enterprise pricing policy is determined. It is established that the process of organizing the accounting of such activities is important for the formation of pricing policy. In this regard, the existing methodological approaches to pricing were presented.

It is determined that the calculation of the price of products is based on information about the costs incurred by the company for its manufacture. Such information is provided by the accounting data. In addition, external factors are taken into account, which make it possible to calculate the maximum possible profit from the sale of manufactured products.
\end{abstract}

The functions of the price through which its economic essence is shown are considered. It is pointed out that it is with the help of the accounting function that the costs of social labor are determined, as well as the cost of society's need for goods; due to the accounting function, price is a means of determining quantitative and qualitative indicators.

The stages of accounting organization in pricing are outlined and their characteristics are given. The role and significance of the accounting apparatus in the pricing system of the business entity are determined. Elements of accounting policy with direct and indirect impact on the pricing process are highlighted. The managerial influence of the accounting policy on the formation of the enterprise price is proved. In addition, the stages of target pricing are considered.

On the basis of the conducted research the corresponding conclusions are made and the directions of the further research and the reasons of its necessity are specified. 

policy.

Keywords: price, costs, accounting, profitability, demand, enterprise, accounting Tabl.: 2. Fig.: 3. Ref.: 11.

\title{
ЗНАЧЕНИЕ УЧЕТНОЙ СОСТАВЛЯЮЩЕЙ ПРОЦЕССА ЦЕНООБРАЗОВАНИЯ НА ПРЕДПРИЯТИИ
}

\author{
КОВАЛЬ Л.В, \\ кандидат экономических наук, доцент \\ кафедры бухгалтерского учета
}

\begin{abstract}
ЛЕПЕТАН И.М., кандидат экономических наук, доцент кафедры бухгалтерского учета, Винницкий национальный аграрный университет
\end{abstract}

(2. Винница)

В статье обосновано значение учетной составляющей процесса иеенобразования на
предприятии.
В частности обозначены определения процесса иценообразования и установлена его зависимость от ряда факторов. Кроме этого, в статье приведена стратегия функиионирования предприятия, в зависимости от финансового состояния. В результате исследования установлено, что иеена напрямую влияет на поведение предприятия на рынке. Выделено разнообразие рынков, на которых работают субъекты хозяйствования $u$ определено их влияние на формирование ценовой политики предприятий. Установлено, что для формирования ценовой политики большое значение имеет процесс организации учета такой деятельности. В связи с этим были представлены существующие методические подходы к установлению ценьы.

Определено, что в основу расчета цены на продукцию возложена информация о расходах, которые понесло предприятие на ее изготовление. Такую информацию предоставляют данные бухгалтерского учета. Кроме этого, учитываются и внешние факторы, позволяющчие рассчитать максимально возможную прибыль от реализации произведенной продукиии.

Рассмотрены функции цены, по которой проявляется ее экономическая сущность. Выделено, что именно с помощью учетной функции определяются затраты общественного труда, а также средства на нужды общества в товаре; благодаря учетной функции иена является средством определения количественных и качественных показателей товарооборота.

Определень этапь организации учета в ценообразовании и приведена их характеристика. Определена роль и значение учетного аппарата в системе ценообразования предприятия. Выделень элементы учетной политики с прямым $u$ косвенным влиянием на прочесс иенообразования. Доказано управляющее воздействие учетной политики на формирование цены предприятия. Кроме этого, рассмотрены этапь иелевого ченообразования.

На основе проведенного исследования сделаны соответствующие выводы и указаны направления дальнейших исследований и причины их необходимости. политика.

Ключевые слова: цена, расходы, учет, доходность, спрос, предприятие, учетная

Табл.: 2. Рис.: 3. Лит.: 11. 
Постановка проблеми. Агроформування відіграють вагому роль у національній економіці. За сучасних кризових реалій вони фактично стали економічними донорами для місцевих бюджетів та держави [1, с. 10]. Зростання прибутковості підприємства залежить не тільки від якості продукції та попиту на неї, а й від цінової політики суб'єкта господарювання. Хоча, з іншого боку, саме цінова політика, певною мірою, формує попит на виготовлену продукцію, товари, надані послуги.

Політика ціноутворення може сприяти завоюванню споживача навіть на європейському ринку, що дасть змогу конкурувати із зарубіжними товаровиробниками. У цьому випадку можна стверджувати про пряму залежність фінансових результатів суб'єкта господарювання від обраної політики ціноутворення. Оптимальна цінова політика має бути гнучкою й дозволяти варіювати встановленими цінами, залежно від ситуації на ринку, водночас забезпечуючи отримання запланованого прибутку. Фінансова стійкість і належний фінансовий стан підприємств залежить і від належного ціноутворення.

Ціна на товар чи продукцію має бути підтверджена якістю такого продукту. Якщо ціна формується завищена, то обсяг проданої продукції скоротиться або буде нульовим.

Для забезпечення відповідного процесу ціноутворення важливим $\epsilon$ оптимальне інформаційне підгрунтя, однією зі складових якого є облікові дані суб'єкта господарювання.

Усе вищезазначене формує актуальність теми дослідження.

Аналіз останніх досліджень i публікацій. Питання процесу ціноутворення досліджувалося багатьма вченими-економістами й науковцями, серед яких: Волошанюк Н.В. [5], Давидов Г.М. [7], Мазур О.С. [3], Калетнік Г.М. [1], Правдюк Н.Л. [2], Свідерська І.М. [5], Тимошик В.Ю. [4], Шинькович А.В. [1] та ін. Зокрема, розглянуто питання формування ціни, досліджено фактори впливу на ціноутворення, вивчено міжнародний досвід цього питання. Однак питанню облікової складової процесу ціноутворення приділено недостатньо уваги.

Формулювання цілей статті. Метою дослідження $є$ обгрунтування значення облікової складової процесу ціноутворення на підприємстві.

Виклад основного матеріалу дослідження. Ціноутворення - складний процес для суб'єкта господарювання. Сучасні умови ведення бізнесу в Україні характеризуються динамічністю та мінливістю політичної і соціально-економічної ситуації, тому підприємства вимушені діяти в умовах підвищеного ризику й невизначеності. За таких умов важливого значення набуває розробка стратегії, яка має спрямовуватись на досягнення визначених цільових параметрів діяльності господарюючих суб'єктів із урахуванням потенційного впливу чинників зовнішнього й внутрішнього характеру [2, с. 104].

Під час формування цінової політики підприємств важливо враховувати індекси споживчих цін на товари й послуги (табл. 1). 
Таблиия 1

Індекси споживчих цін на товари й послуги в Україні, 2011-2020 рр., \%

\begin{tabular}{|c|c|c|c|c|c|c|c|c|c|c|c|}
\hline \multirow{2}{*}{ Показники } & \multicolumn{10}{|c|}{ Рік } & \multirow{2}{*}{$\begin{array}{c}\text { Відхилення } \\
2020-2011 \\
(+/-)\end{array}$} \\
\hline & 2011 & 2012 & 2013 & 2014 & 2015 & 2016 & 2017 & 2018 & 2019 & 2020 & \\
\hline Індекс споживчих цін & 108,0 & 100,6 & 99,7 & 112,1 & 148,7 & 113,9 & 114,4 & 110,9 & 107,9 & 102,7 & $-5,3$ в.п. \\
\hline $\begin{array}{l}\text { Продукти харчування та } \\
\text { безалкогольні напої }\end{array}$ & 106,4 & 97,9 & 97,8 & 112,2 & 145,9 & 109,0 & 112,9 & 111,1 & 108,0 & 102,7 & $-3,7$ в.п. \\
\hline $\begin{array}{l}\text { Алкогольні напої, тютюнові } \\
\text { вироби }\end{array}$ & 116,0 & 107,5 & 108,4 & 116,7 & 133,2 & 112,6 & 126,2 & 118,5 & 115,6 & 110,7 & $-5,3$ в.п. \\
\hline Одяг і взугтя & 101,6 & 98,9 & 97,0 & 102,0 & 133,1 & 116,1 & 102,4 & 101,8 & 100,2 & 95,4 & $-6,2$ в.п. \\
\hline $\begin{array}{l}\text { Житло, вода, електроенергія, газ й } \\
\text { інші види палива }\end{array}$ & 117,1 & 102,6 & 100,3 & 116,2 & 215,8 & 135,1 & 126,7 & 106,8 & 108,0 & 97,0 & $-20,1$ в.п. \\
\hline $\begin{array}{l}\text { Предмети домашнього вжитку, } \\
\text { побутова техніка й поточне } \\
\text { утримання житла }\end{array}$ & 102,9 & 101,9 & 99,7 & 111,7 & 145,9 & 109,4 & 102,9 & 106,1 & 102,9 & 99,3 & $-3,6$ в.п. \\
\hline Охорона здоров'я & 106,7 & 103,7 & 102,3 & 116,5 & 137,6 & 111,7 & 106,2 & 108,8 & 106,7 & 105,3 & $-1,4$ в.п. \\
\hline Транспорт & 117,6 & 108,2 & 102,0 & 124,5 & 136,8 & 106,5 & 114,2 & 115,7 & 104,1 & 98,1 & $-19,5$ в.п. \\
\hline Зв'язок & 100,6 & 102,0 & 101,2 & 100,9 & 105,9 & 103,9 & 108,7 & 111,0 & 115,5 & 106,5 & $+5,9$ в.п. \\
\hline Відпочинок і культура & 103,7 & 101,5 & 99,7 & 110,7 & 142,7 & 112,2 & 104,3 & 104,4 & 102,4 & 98,2 & $-5,5$ в.п. \\
\hline Освіта & 108,9 & 105,1 & 103,4 & 103,2 & 117,9 & 116,5 & 111,9 & 114,6 & 113,4 & 113,6 & $+4,7$ в.п. \\
\hline Ресторани й готелі & 107,8 & 104,6 & 101,9 & 106,7 & 124,3 & 113,1 & 113,6 & 115,3 & 111,1 & 105,9 & $-1,9$ в.п. \\
\hline Різні товари й послуги & 107,3 & 103,6 & 102,0 & 111,4 & 138,6 & 110,3 & 105,4 & 109,5 & 109,8 & 106,4 & $-0,9$ в.п. \\
\hline
\end{tabular}

Потрібно зазначити, що індекс споживчих цін (індекс інфляції) характеризує зміни загального рівня цін, виявляє зміну вартості фіксованого споживчого набору товарів і послуг у поточному періоді щодо минулого періоду. Водночас споживчий набір товарів і послуг є єдиним для всіх регіонів України.

Індекс споживчих цін $є$ показником зміни сукупної ціни одного й того ж самого набору товарів і послуг у різні періоди. Сукупна ціна набору товарів $\mathrm{i}$ послуг у базисному періоді приймається за 100, зміни в наступні періоди виражаються у відсотках до вартості базисного періоду. Отже, ціни на товари, продукцію, роботи та послуги впливають на індекс споживчих цін.

За даними таблиці 1, на прикладі порівняння даних індексу споживчих цін за наведені роки, можна зробити висновок, що вартість набору товарів i послуг найбільше збільшилася у 2015 році - на 48,7\%, порівнюючи з минулим роком. Водночас найбільший ріст індексу споживчих цін прослідковується у цьому ж році на житло, воду, електроенергію, газ й інші види палива, i становить $215,8 \%$, що свідчить про ріст цін більше ніж у два рази.

Обгрунтування, затвердження і реалізація цінової політики суб'єкта господарювання $\epsilon$ досить складним процесом, який повинен бути налагоджений так, щоб встановлені ціни задовольняли запити підприємства щодо отримання прибутку й влаштовували споживачів.

Основними цілями підприємницької діяльності, досягненню яких має слугувати ціноутворення, $є$ наступні:

1) забезпечення сталого функціонування підприємства - в умовах активної конкуренції, а також у випадку зміни споживчих смаків, коли $\mathrm{i}$ виникає ризик надмірного розміру пропозиції, що спонукає підприємство знижувати ціни до рівня покриття витрат, а отримання прибутку не стає 
пріоритетним завданням. Проте така ситуація може розглядатися тільки в короткостроковому періоді;

2) максимізація прибутку в короткостроковому періоді - розглядається як певна ціль, коли підприємство намагається 3 найбільшою користю використати кон'юнктуру ринку, а також у разі невизначеності умов діяльності підприємства в майбутньому;

3) максимізація обороту в короткостроковому періоді - реалізується через включення відсотку комісійних на збут продукції;

4) утримання ринку - зберігання існуючого положення або сприятливих умов діяльності на ринку. Підприємство відстежує ситуацію на ринку (виробництво нових товарів, вивчення поводження конкурентів на ринку), намагаючись уникнути значного зростання чи зниження цін. Крім того, важливо зменшувати витрати виробництва для формування запасу фінансової стійкості за несприятливої ситуації на ринку;

5) формування довгострокової стратегії підприємства за показником частки ринку, тобто досягнення лідерства на ньому. У цьому випадку доцільним є встановлення ціни, нижчої, ніж у конкурентів, що дозволяє збільшувати частку ринку. Вважається, що зростання збуту сприяє зростанню прибутку завдяки реалізації і зниженню витрат на одиницю продукції;

6) покращення якісних характеристик підприємства - ціль, яка притаманна більшості підприємств. Додаткові витрати на забезпечення якості продукції підприємства пов'язані 3 проведенням науково-дослідницьких i конструкторських робіт, рекламних заходів, тому ціни на товари таких підприємств вищі, ніж у конкурентів. Для здійснення такої політики суб'єкт повинен мати стабільне фінансове становище, репутацію виробника якісних товарів та попит на таку продукцію.

Зазначені цілі цінової політики пов’язані між собою. Досягнення максимізації прибутку в короткостроковій перспективі може призвести до збитків у майбутньому. Досягнення цілей відбувається в різних періодах, але всі вони повинні сприяти довгостроковій максимізації прибутку [9, с. 183].

Розробка цінової політики підприємства залежить від стратегії його розвитку й поточних цілей. Залежно від фінансового стану суб'єкт господарювання може націлювати свою діяльність на: виживання, зростання поточного прибутку до максимуму й формування монополії (якісної чи кількісної).

У першому випадку напрямок розвитку обумовлений скрутним фінансовим становищем суб'єкта господарювання, що спонукає до необхідності зниження ціни до допустимого мінімуму. Така ситуація може привести до того, що через певний проміжок часу суб'єкт господарювання буде змушений припинити свою діяльність.

У другому випадку суб'єкт господарювання займає надійну позицію на ринку. Водночас для нього поточні фінансові показники важливіші за довгострокові. Щодо ціноутворення, то підприємство формує ціну так, щоб отримати максимальний прибуток i повністю покрити й відшкодувати свої витрати. 
За умови, якщо підприємство формує монополію, ціна на товар може коливатися від мінімуму до максимуму. За мінімальної ціни й високої якості досягається завоювання максимальної частки ринку. Після цього монополіст може встановлювати й вищу ціну на той же товар. Допустима також монополія за якісними характеристиками товарів. За таких умов встановлюється ціна відповідного рівня, що є допустимим у такій ситуації.

Отже, ціна прямо впливає на поведінку суб'єкта господарювання на ринку. Різне ставлення до ціни пов'язане 3 різними завданнями, які розв'язуються підприємством.

Окрім позиції підприємства на процес ціноутворення впливає також ринкове середовище, у якому працює суб'єкт господарювання. Виокремлюють наступні типи ринків: ринок прямої (чистої) конкуренції, ринок монополістичної конкуренції, ринок олігополістичної конкуренції та ринок прямої (чистої) монополії. Щодо впливу підприємства на формування ціни в умовах господарювання того чи іншого типу ринку, то потрібно відмітити, що суб'єкт господарювання здійснює найбільший вплив на формування цінової політики в умовах чистої монополії. На противагу цьому, ринок чистої конкуренції не дає можливості підприємству впливати на формування ціни: суб'єкт господарювання змушений продавати товар за цінами, встановленими на такому ринку. Ринки олігополістичної та монополістичної конкуренції надають можливість часткового впливу на процес ціноутворення.

Отже, під час формування ціни, суб'єкт господарювання повинен чітко розробити методику розрахунку цін залежно від типу ринку.

Сьогодні домінують три методичних підходи до встановлення цін:

1) на основі ринкових цін;

2) на базі витрат (змінних чи повних);

3) на договірній основі.

Після вибору ціни продукту, яка діє на зовнішньому ринку, потрібно здійснити низку коригувань, пов'язаних із характеристиками продукту, транспортними й непрямими витратами. У разі виконання зазначених вище умов внутрішні ціни мають дорівнювати ринковим. Так, якщо внутрішні ціни будуть вищими за ринкові, то окремі структурні підрозділи не будуть займатися виробництвом, а здійснюватимуть відповідні закупівлі на зовнішніх ринках. I навпаки, якщо внутрішні ціни будуть меншими від ринкових, то для виробничих підрозділів вигідно реалізовувати продукт на зовнішніх ринках [5, с. 100].

Базою для розрахунку ціни на продукцію є інформація про витрати, які отримало підприємство під час виготовлення цієї продукції. Зазначену інформацію отримують із даних бухгалтерського обліку. Поряд із цим враховуються і зовнішні фактори, які дають можливість розрахувати максимально можливий прибуток від реалізації виготовленої продукції.

Економічна сутність ціни проявляється, насамперед, через виконання нею наступних функцій:

- облікової;

- збалансування попиту та пропозиції або регулюючої;

- стимулюючої; 
- розподільчої;

- засобу розміщення виробництва або критерій раціонального розміщення виробництва [3, с. 17].

Кожна 3 функцій ціни $\epsilon$ досить важливою $\mathrm{i}$ всі разом вони $\epsilon$ взаємодоповнюючими. Так, розподільча функція дає можливість здійснювати перерозподіл частини доходів суб'єктів господарювання та населення за допомогою цін, що мають відхилення від вартості. Регулююча функція дає змогу врівноважити попит і пропозицію. Стимулююча функція дозволяє вивести ефективність господарювання на новий рівень, чим стимулює підприємство до кращих результатів і показників діяльності. Функція засобу розміщення виробництва дозволяе визначити критерії його раціонального розміщення, враховуючи ряд факторів і стан суб’єкта господарювання.

За допомогою облікової функції ціни визначаються витрати суспільної праці, а також вартість потреби суспільства в товарі. Завдяки обліковій функції, ціна $\epsilon$ засобом визначення кількісних і якісних показників. До кількісних показників належать: валовий внутрішній продукт, національний дохід, обсяг капіталовкладень, обсяг товарообороту, обсяг продукції, виготовленої різними підприємствами й галузями загалом. Якісними показниками $є$ прибутковість, продуктивність праці, фондовіддача, продуктивність витрат й ін. Облікова функція має велике значення під час визначення кон'юнктури ринку на товар залежно від його життєвого циклу [4, с. 121].

Для забезпечення виконання ціною облікової функції необхідно на підприємстві належно організувати облік. Організація обліку в ціноутворенні проходить декілька етапів (табл. 2).

Таблиия 2

\section{Етапи організації обліку в ціноутворенні}

\begin{tabular}{|c|c|c|}
\hline № п/п & Етап & Характеристика \\
\hline 1 & \begin{tabular}{|c|} 
Постановка \\
завдань \\
ціноутворення \\
\end{tabular} & $\begin{array}{l}\text { Припускається ринкове позиціонування, яке визначає стратегія ціноутворення } \\
\text { підприємства - забезпечення виживання, максимізація поточного прибутку, завоюваня } \\
\text { лідерства за показниками частки ринку або за показниками якості товару. }\end{array}$ \\
\hline 2 & $\begin{array}{c}\text { Визначення } \\
\text { попиту і його } \\
\text { еластичності }\end{array}$ & $\begin{array}{l}\text { Для цього використовуються такі прийоми оцінки попиту, як експеримент, пряме } \\
\text { інтерв’ю, статистичні висновки. Залежність між ціною і відповідним рівнем попиту } \\
\text { зображується на кривій попиту (у звичайній ситуації попит і ціна знаходяться в } \\
\text { обернено пропорційній залежності). Попит, як правило, визначає максимальну ціну, яку } \\
\text { підприємство може призначити за свій товар. }\end{array}$ \\
\hline 3 & Оцінка витрат & $\begin{array}{l}\text { Мінімальна ціна визначається витратами підприємства (ціна товару за ринкових умов } \\
\text { повинна повністю покривати всі витрати } 3 \text { його виробництва, розподілу й збут,, } \\
\text { включаючи справедливу норму прибутку за докладені зусилля і ризик). }\end{array}$ \\
\hline 4 & $\begin{array}{l}\text { Аналіз цін і } \\
\text { товарів } \\
\text { конкурентів }\end{array}$ & $\begin{array}{l}\text { На встановлення фірмою середнього діапазону цін впливають ціни конкурентів і їх } \\
\text { ринкові реакції, тому для обгрунтованого ціноутворення підприємству необхідно } \\
\text { постійно аналізувати ціни і якість товарів своїх конкурентів (ціни товарів конкурентів і } \\
\text { товарів-замінників дають середній рівень). }\end{array}$ \\
\hline 5 & $\begin{array}{c}\text { Вибір методу } \\
\text { ціноутворення }\end{array}$ & $\begin{array}{l}\text { Види методів ціноутворення: сума середніх витрат і прибутку; аналіз беззбитковості й } \\
\text { забезпечення цільового прибутку; встановлення ціни, виходячи } 3 \text { цінності товару, що } \\
\text { відчувається; встановлення ціни на основі рівня поточних цін; встановлення ціни на } \\
\text { основі закритих торгів. }\end{array}$ \\
\hline 6 & $\begin{array}{c}\text { Встановлення } \\
\text { остаточної ціни }\end{array}$ & $\begin{array}{l}\text { Базується на психології ціносприйняття (ціна є показником якості, наявність знижок). } \\
\text { Водночас потрібно дотримуватися антимонопольного законодавства, а саме: не } \\
\text { допускати фіксації цін, цінової дискримінації, немотивованого зростання цін, змови } 3 \\
\text { іншими постачальниками цього товару. }\end{array}$ \\
\hline
\end{tabular}


Розглянувши етапи організації обліку в ціноутворенні, потрібно відмітити наступне:

- етапи організації обліку в ціноутворенні розміщені в логічній послідовності;

- кожен наступний етап доповнює та продовжує попередній;

- формування наступного етапу не можливе без завершення попереднього;

- виключення одного з етапів призведе до порушення процесу організації обліку суб'єкта господарювання загалом.

Належну увагу в процесі ціноутворення потрібно приділити обліковому апарату суб'єкта господарювання. Саме обліковий апарат формує управлінську інформацію, що містить дані про витрати, кошторис й інші цінові компоненти. Особливості й принципи формування ціни мають бути викладені в наказі про облікову політику.

У наказі про облікову політику зазначаються альтернативні варіанти організації та ведення обліку, обрані суб'єктом господарювання самостійно. Водночас враховується ряд факторів, таких як: особливості та специфіка діяльності, кваліфікація обліковців, автоматизація обліку, розмір підприємства тощо.

Під час формування наказу про облікову політику усі іï елементи можна умовно поділити на дві групи: 3 прямим і непрямим впливом на процес ціноутворення.

Так, до першої групи елементів можна віднести: визначення сегментів і принципів ціноутворення у внутрішньогосподарських розрахунках; вибір методу оцінки активів і зобов'язань за операціями, які розглядаються як операції пов'язаних сторін (рис. 1).

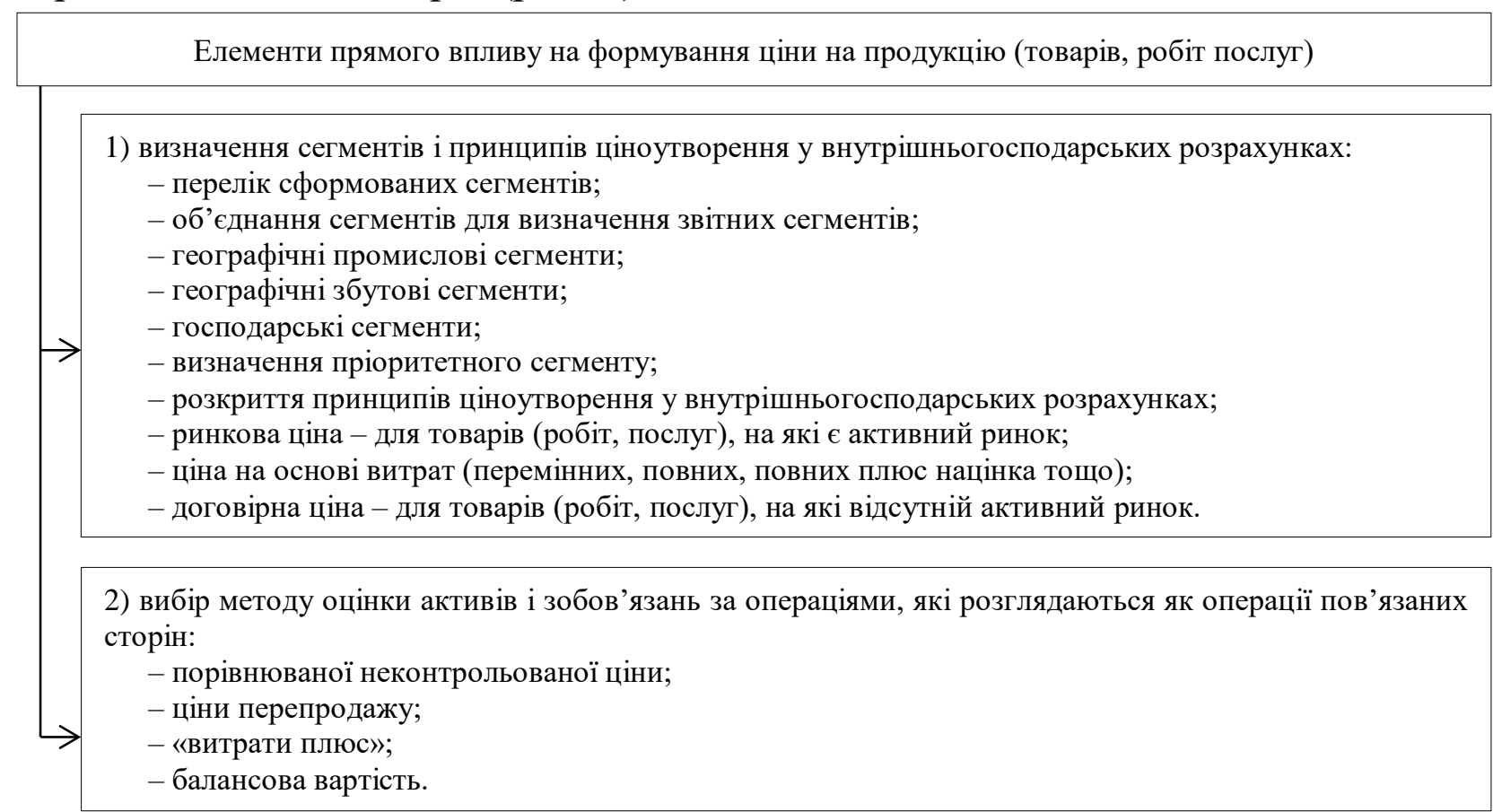

Рис. 1. Елементи облікової політики прямого впливу на формування ціни продукції

Джерело: сформовано авторами на основі даних [7, с. 210-212] 
Елементи першої групи націлені на сегментний вибір і застосування принципів ціноутворення на його основі. Водночас здійснюється вибір методів оцінки активів і зобов'язань за операціями пов’язаних сторін.

Друга група елементів містить:

- застосування методів амортизації необоротних активів із деталізацією застосування методів до окремих груп;

- облік запасів;

- формування собівартості продукції;

- загальновиробничі витрати (рис. 2).

\begin{tabular}{|l} 
Елементи непрямого впливу на формування ціни на продукцію (товарів, робіт послуг) \\
\hline $\begin{array}{l}\text { 1) застосування методів амортизації необоротних активів із деталізацією застосування методів до } \\
\text { окремих груп; }\end{array}$
\end{tabular}

2) облік запасів:

2.1) відкриття окремих субрахунків обліку транспортно-заготівельних витрат із кожного виду запасів із подальшим розподілом витрат після їх використання;

2.2) без відкриття окремих субрахунків обліку транспортно-заготівельних витрат із включенням їх до вартості запасів із подальшим списанням одночасно з використання відповідних запасів;

2.3) застосування окремого субрахунку обліку транспортно-заготівельних витрат товарів із подальшим розподілом витрат після використання товарів;

2.4) застосування одного з методів оцінки вибуття запасів для кожного з окремих видів запасів, які мають одне призначення та однакові умови використання;

2.5) під час застосування методу середньозваженої собівартості:

- оцінка вибуття проводиться один раз на місяць - для запасів, які використовуються на підприємстві під час виробництва продукції (робіт, послуг);

- оцінка вибуття проводиться на дату проведення операції - для запасів, які використовуються в торгівельних операціях;

3) формування собівартості продукції:

- наводиться повний перелік і склад статей калькулювання продукції, робіт, послуг;

4) загальновиробничі витрати:

- наводиться повний перелік і склад змінних та постійних витрат;

- вказується застосування бази розподілу витрат за об’єктами: години праці; заробітна плата; об’єми діяльності; прямі матеріальні витрати тощо.

\section{Рис. 2. Елементи облікової політики непрямого впливу на формування ціни на продукцію}

Джерело: сформовано авторами на основі даних [7, с. 212-215]

Елементи облікової політики прямого пливу на ціноутворення фактично формуються на основі даних відповідних Національних положень (стандартів) бухгалтерського обліку і $є$ методичними складовими облікової політики.

Методичні складові облікової політики процесу ціноутворення для потреб як фінансового, так і управлінського обліку містять: складові первісної вартості придбаних запасів (товарів для перепродажу, сировини й матеріалів для виробництва), методи обліку й розподілу транспортно-заготівельних витрат (пряме включення до первісної вартості запасів із акумулюванням на окремому рахунку й подальшим розподілом), методи оцінки запасів за їхнього вибуття (ФІФО, середньозваженої собівартості, ідентифікованої собівартості, 
нормативних витрат, за цінами продажу), порядок визначення первісної вартості готової продукції (робіт, послуг). Стратегічні форми цінової політики й способи ऑiі здійснення безпосередньою випливають із ринкової стратегії господарюючого суб'єкта й відображаються як елемент обліково-економічної політики. Залежно від застосованої комбінації варіантів ринкової стратегії обирається конкретна форма здійснення цінової політики.

Під час формування ціни, суб'єкт господарювання має врахувати готовність покупців платити за продукцію, товари, роботи й послуги. Тобто визначити цільову ціну.

Виділяють чотири основні етапи застосування методу цільового ціноутворення (рис. 3).

Етапи цільового ціноутворення
Вибір цільової ціни, заснованої на попиті покупця на продукцію і рівні цін конкурента.

Puc. 3. Етапи застосування методу цільового ціноутворення в інформаційній системі облікового забезпечення процесу прийняття рішень

Джерело: сформовано авторами на основі даних [8, с. 210]

Зазначені етапи дають змогу забезпечити задоволення інтересів товаровиробників і потреб споживачів. Методика формування ціни вітчизняних товаровиробників на свою продукцію має певні особливості, які формуються під впливом стратегії розвитку підприємства. Вибір методу ціноутворення складний та відповідальний процес, що має враховувати низку факторів. Тому у практичній діяльності прослідковується використання поєднання декількох методів ціноутворення одним суб' єктом господарювання.

Якщо суб'єкту господарювання потрібно скоригувати собівартість, то необхідно переглянути деякі елементи облікової політики. Отже, облікова політика набуває управлінської спрямованості. Саме управлінська спрямованість облікової політики має сенс, оскільки повною мірою може впливати на процеси господарювання.

Висновки. Формування цінової політики підприємства напряму залежить від ряду факторів та базується, в основному, на облікових даних. Організація облікового процесу для ціноутворення передбачає формування відповідних елементів облікової політики підприємства, що надає їй управлінського спрямування.

Сьогодні, під час формування ціни, потрібно використовувати усі методи 
ціноутворення в сукупності, враховуючи також індекс ціноутворення за відповідний період. Це дасть змогу встановити таку ціну, яка б не тільки покривала витрати виробництва, а й забезпечила товаровиробнику певний рівень прибутку.

Перспективами подальших досліджень $є$ пошук напрямків оптимізації процесу ціноутворення, 3 врахуванням даних обліку, що забезпечить підприємству довгострокове благополуччя та прихильність споживачів.

\section{Список використаних джерел}

1. Калетнік Г.М., Шинькович А.В. Оцінка організаційно-інформаційного забезпечення антикризового управління агроформувань. Економіка, фінанси, менеджмент: актуальні питання науки і практики. 2020. № 1 (51). С. 7-23. DOI: 10.37128/2411-4413-2020-1.

2. Правдюк Н.Л. Облікове забезпечення управління маркетинговою стратегією підприємства. Економіка, фінанси, менеджмент: актуальні питання науки і практики. 2019. № 2 (42). C. 100-115. DOI: 10.37128/2411-44132019-2-9.

3. Мазур О.С. Ринкове ціноутворення: навч. посіб. Київ: Центр учбової літератури, 2012. $480 \mathrm{c}$.

4. Тимошик В.Ю. Формування ціни на підприємстві в умовах сучасного ринку. Сталий розвиток економіки. 2013. № 4. С. 121-124.

5. Свідерська I.М., Волошанюк Н.В. Трансфертне ціноутворення як інструмент фінансового контролінгу: проблематика практичного використання в Україні. Фінанси Украӥни. 2014. № 8. С. 97-111. $304 \mathrm{c}$.

6. Салимжанов И.К. Ценообразование: учебник. Москва: КНОРУС, 2007.

7. Давидов Г.М., Савченко В.М., Пальчук О.В. Облікова політика: навч. посіб. Кропивницький: ПП «Ексклюзив-Систем», 2017. 362 с.

8. Сенишин О.С., Кривешко О.В. Маркетинг: навч. посібник. Львів: Львівський національний університет ім. Івана Франка, 2020. 347 с.

9. Горемикін В.А. Планування на підприємстві. Москва: Філін, 2003. $328 \mathrm{c}$.

10. Офіційний сайт Державної служби статистики України. URL: http://www.ukrstat.gov.ua (дата звернення: 20.12.2021).

11. Чичуліна К.В., Хвостенко Н.А. Сучасний стан формування облікової політики в ціноутворенні. Східна Свропа: економіка, бізнес та управління. 2017. Вип. 6 (11). С. 375-378.

\section{References}

1. Kaletnik, G.M., \& Shynkovych, A.V. (2020). Otsinka orhanizatsiynoinformatsiynoho zabezpechennya antykryzovoho upravlinnya ahroformuvan [Assessment of organizational and information support of anti-crisis management of agricultural formations]. Ekonomika, finansy, menedzhment: aktualni pytannya nauky i praktyky - Economy, finances, management: topical issues of science and practical activity, 1 (51), 7-23. DOI: 10.37128/2411-4413-2020-1 [in Ukrainian]. 
2. Pravdyuk, N.L. (2019). Oblikove zabezpechennya upravlinnya marketynhovoyu stratehiyeyu pidpryyemstva [Accounting management of marketing strategy of the enterprise]. Ekonomika, finansy, menedzhment: aktualni pytannya nauky i praktyky - Economy, finances, management: topical issues of science and practical activity, 2 (42), 100-115 [in Ukrainian].

3. Mazur, O.E. (2012). Rynkove tsinoutvorennya [Market pricing]. Kyiv: Tsentr uchbovoyi literatury [in Ukrainian].

4. Timoshik, V.Yu. (2013). Formuvannya tsiny na pidpryyemstvi v umovakh suchasnoho rynku [Price formation at the enterprise in the modern market]. Stalyy rozvytok ekonomiky - Sustainable economic development, 4, 121-124 [in Ukrainian].

5. Sviderska, I.M., \& Voloshanyuk, N.V. (2014). Transfertne tsinoutvorennya yak instrument finansovoho kontrolinhu: problematyka praktychnoho vykorystannya $\mathrm{v}$ Ukrayini [Transfer pricing as a tool of financial controlling: issues of practical use in Ukraine]. Finansy Ukrayiny - Finance of Ukraine, 8, 97-111 [in Ukrainian].

6. Salimzhanov, I.K. (2007) Tsenoobrazovanye [Pricing]. Moscow: KNORUS. [in Russian].

7. Davydov, H.M., Savchenko, V.M., \& Palchuk, O.V. (2017). Oblikova polityka [Accounting policy]. Kropyvnytskyy: PP «Eksklyuzyv-System» [in Ukrainian].

8. Senyshyn, O.S., \& Kryveshko, O.V. (2020). Marketynh [Marketing]. Lviv: Lvivskyy natsionalnyy universytet im. Ivana Franka [in Ukrainian].

9. Goremikin, V.A. (2003). Planuvannya na pidpriyemstvi [Planning at the enterprise]. Moskow: Filin [in Ukrainian].

10. Ofitsiinyi sait Derzhavnoi sluzhby statystyky Ukrainy [Official site of the State Statistics Service of Ukraine]. ukrstat.gov.ua. Retrieved from: www.ukrstat.gov.ua [in Ukrainian].

11. Chychulina, K.V., \& Xvostenko, N.A. (2017). Suchasnyj stan formuvannya oblikovoyi polityky $\mathrm{v}$ cinoutvorenni [The current state of formation of accounting policies in pricing]. Sxidna Yevropa: ekonomika, biznes ta upravlinnya Eastern Europe: Economy, Business and Management, 6 (11), 375-378 [in Ukrainian].

\section{Відомості про авторів}

КОВАЛЬ Любов Віталіївна - кандидат економічних наук, доцент кафедри бухгалтерського обліку, Вінницький національний аграрний університет (21008, м. Вінниця, вул. Сонячна, 3, e-mail: kovalstar@ meta.ua).

ЛЕПЕТАН Інна Михайлівна - кандидат економічних наук, доцент кафедри бухгалтерського обліку, Вінницький національний аграрний університет (21008, м. Вінниця, вул. Сонячна, 3, e-mail: lepetan_inna@i.ua).

KOVAL Liubov - Candidate of Economic Sciences, Associate Professor of Accounting Department, Vinnytsia National Agrarian University (21008, Vinnytsia, 3, Soniachna Str., e-mail: kovalstar@meta.ua).

LEPETAN Inna - Candidate of Economic Sciences, Associate Professor of the Department of Accounting, Vinnytsia National Agrarian University (21008, 
Vinnytsia, 3, Soniachna Str., e-mail: lepetan_inna@i.ua).

КОВАЛЬ Любовь Витальевна - кандидат экономических наук, доцент кафедры бухгалтерского учета, Винницкий национальный аграрный университет (21008, г. Винница, Солнечная, 3, e-mail: kovalstar@ meta.ua).

ЛЕПЕТАН Инна Михайловна - кандидат экономических наук, доцент кафедры бухгалтерского учета, Винницкий национальный аграрный университет (21008, г. Винница, ул. Солнечная, 3, e-mail: lepetan_inna@i.ua).

УДК 658.14/17:[688:005.921.1:33]

DOI: 10.37128/2411-4413-2021-4-12

МЕТОДИЧНІ

АСПЕКТИ АНАЛІЗУ

УПРАВЛІННЯ

ФІНАНСОВОЮ

БЕЗПЕКОЮ

ПШДПРИЕМСТВА
ФЕДОРИНИНА Л.І., кандидат історичних наук, доцент кафедри аналізу та аудиту, Вінницький національний аграрний університет (м. Вінниця)

У статті розкрито сутність і проаналізовано структурно-елементне наповнення поняття «фінансова безпека підприємства». Встановлено, що категоріальна сутність фінансової безпеки опосередкована оточенням суб'єкта підприємництва й формується відносинами, у які він вступає в процесі своєї практичної діяльності. Визнано, щяо фінансову безпеку підприємства доиільно трактувати як спроможність протидіяти наявним $i$ можливим небезпекам, які здатні завдати фінансових збитків, трансформувати структуру капіталу чи взагалі призвести підприємство до банкрутства.

Досліджено, щзо забезпечення належного рівня фінансової безпеки сільськогосподарських підприсмств можливе через систему ї управління. Наведено структуровану систему управління фінансовою безпекою підприємства, яка охоплює перелік зовнішніх $і$ внутрішніх загроз, завдання та алгоритм управління, а також підсистеми методичного, нормативно-правового, фінансового, технічного, інформачійного, організачійного, кадрового забезпечення.

Конкретизовано й систематизовано методичний інструментарій моніторингу, аналізу й оцінки рівня фінансової безпеки підприємства. Доведено, щзо оцінювання та аналіз стану фінансової безпеки є моніторингом основних соціально-економічних показників $і$ їхнім зіставленням з граничними значеннями. Наведено принципи формування інструментарію оичнки фінансової безпеки підприємства.

Надано характеристику методичним підходам щзодо кількісно-структурного наповнення інструментарію оцінки рівня фінансової безпеки підприємства.

Для комплексної оцінки рівня фінансової безпеки підприємств запропоновано використовувати структуровані групи показників за напрямами фінансового аналізу. Розроблено структурно-логічний алгоритм практичної реалізації методичних підходів аналізу управління фінансовою безпекою підприємства.

Ключові слова: підприємство, фінансова безпека, фінансовий аналіз, індикатор, порогові значення, ризик.

Табл.: 4. Рис.: 2. Літ.: 18.

\section{METHODOLOGICAL ASPECTS OF ANALYSIS OF FINANCIAL SECURITY MANAGEMENT OF THE ENTERPRISE}

